\title{
LXIII. Note on Mr. Potter's Reply
}

\section{William R. Hamilton Esq.}

To cite this article: William R. Hamilton Esq. (1833) LXIII. Note on Mr. Potter's Reply, Philosophical Magazine Series 3, 2:11, 371-371, DOI: 10.1080/14786443308648061

To link to this article: http://dx.doi.org/10.1080/14786443308648061

册 Published online: 01 Jun 2009.

Submit your article to this journal $\pi$

III Article views: 2

Q View related articles $\sqsubset$ 
much interest in the present stage of our knowledge of physical operations.

[To be continued.]

LXIII. Note on Mr. Potter's Reply. By William R. HAMinton, Esq. Andrevos' Professor of Astronony in the University of Dublin, and Royal Astronomer of Ireland*.

GROM Mr. Potter's Reply, published in the April Number of the London and Edinburgh Philosophical Magazine, I collect some additional facts respecting his experiment of prismatic interference, which do not seem to have been stated in his first account of that experiment. In Mr. Potter's first paper, the stress of his objection to the undulatory theory of light seemed to be laid on the observed direction of a certain deviation; to which he opposed his calculated decrease of a certain hyperbolic ordinate. I showed that this observed fact, of deviation in the observed direction (towards the thickness of the prism), could be accounted for by the prismatic aberration of figure, which changed the decreasing hyperbolic ordinate to an increasing ordinate of a certain other curve. But I was of course aware that this prismatic aberration, though a cause acting in the observed direction, might not be energetic enough to account for the whole, or even for the greatest part of the observed effect; and that whether aberration was, or was not, an adequate as well as a real cause (on the undulatory theory of light), must depend on the comparison of my calculated formula with the observed magnitude of the deviation, of which Mr. Potter had not given any measure, or even any estimate. I am happy to have been the means of inducing Mr. Potter to bring forward some additional testimony on this important point : and willingly admit, that according to this new testimony, there remains, after allowing for my suggestions, a large residual phænomenon.

Dublin, April 13, 1833.

LXIV. Revieres, and Notices respecting New Books.

Journal of the Asiatic Society of Calcutta, Nos. 1, 2, and 3 ; with Plates. Calcutta, 1832.

T ${ }^{\mathrm{E}}$ are particularlydesirous of calling the attention of our readers to this valuable monthly periodical, which we are afraid is by no means so well known in Europe as its merits entitle it to be. The present Numbers form the continuation of a scientific journal, published also

* Communicated by the Author.

$3 \mathrm{~B} 2$ 